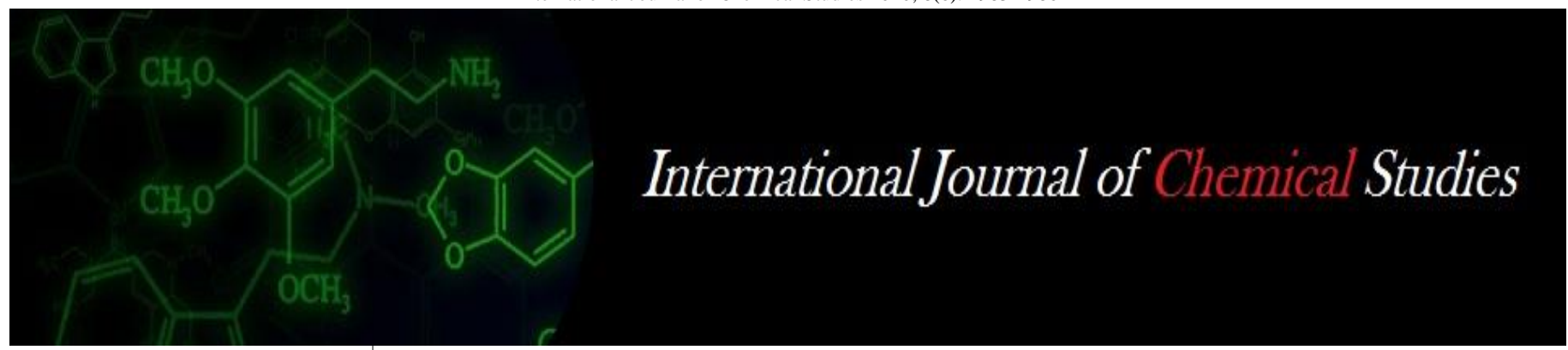

P-ISSN: 2349-8528

E-ISSN: 2321-4902

www.chemijournal.com

IJCS 2020; 8(6): 1983-1986

(C) 2020 IJCS

Received: 20-08-2020

Accepted: 29-10-2020

Saroj Dahiya

Department of Foods and

Nutrition, CCS Haryana

Agricultural University, Hisar,

Haryana, India

Suman

Department of Foods and

Nutrition, CCS Haryana

Agricultural University, Hisar,

Haryana, India

Corresponding Author: Suman

Department of Foods and

Nutrition, CCS Haryana

Agricultural University, Hisar,

Haryana, India

\section{Physico-chemical and nutritional characteristics of coarse cereal grains, Tulsi and their composite flours}

\section{Saroj Dahiya and Suman}

DOI: https://doi.org/10.22271/10.22271/chemi.2020.v8.i6ab.11058

\begin{abstract}
The present investigation aims to evaluate the physico-chemical and nutritional characteristics of pearl millet, sorghum, oat, chickpea grains and Tulsi and their composite flours. Six types of composite flours were prepared. Three composite flours were prepared from blanched pearl millet: sorghum: dehusked oat: germinated chickpea in ratios of 80:5:5:10 (Type-I), 60:10:10:20 (Type-II) and 40:15:15:30 (TypeIII) (W/W), three composite flours consisted of blanched pearl millet: sorghum: dehusked oat: germinated chickpea: Tulsi leaves in ratios of 80:5:5:5:5 (Type-IV), 60:10:10:15:5 (Type-V) and 40:15:15:25:5 (Type-VI) (W/W). The results revealed that chickpea grains had significantly $(P<0.05)$ higher seed weight, seed volume and seed density as compared to other grains. Sedimentation value and water absorption capacity were significantly higher in sorghum and lower in chickpea flour. The protein content was significantly higher in chickpea and crude fat content was significantly higher in pearl millet than other grains. Tulsi leaves had significantly higher crude fibre and ash content. As the level of sorghum, oat and chickpea flour increased in composite flours, the crude protein, crude fibre and ash content increased, while, crude fat decreased. Supplementation of Tulsi leaves powder significantly $(P<0.05)$ increased the ash and crude fibre content of composite flours.
\end{abstract}

Keywords: Coarse cereals, physico-chemical, nutritional, Tulsi, composite flour

\section{Introduction}

India is the largest producer of many kinds of coarse cereals which includes pearl millets, sorghum, oats, barley, finger millets, foxtail millet etc. These are largely grown in the semiarid tropical regions of Asia and Africa, under rain-fed farming systems with little external inputs with grain yield levels being low (often less than 1 tonne/ha) (Rai et al., 2008) ${ }^{[13]}$. They form staple foods for a large segment of the population in the semi-arid tropics of Asia and Africa. Among these, pearl millet (Pennisetum glucum) and sorghum (Sorghum bicolor moench L.) are unique millets rich in dietary fibre, micronutrients and phytochemicals (Bouis, 2000) ${ }^{[4]}$. The coarse cereals and millets require more cooking time and have relatively poor digestibility and low availability of minerals due to presence of inherent anti nutritional factor which limit their uses in various food preparations. The food uses of these crops are very much restricted to traditional consumers. The nutritional and sensory qualities of millet products are limited by the deficiency of certain essential amino- acids, lower digestibility, presence of phenolic compounds, and coarse nature of grain and rapid development of rancidity of bitterness in the flour after milling. Efforts are needed to improve and optimize methods which could improve their acceptability and availability of nutrients. Soaking, germination, cooking and fermentation may be good choice in order to enhance the nutritional quality and utility of these grains. Oats (Avena sativa L.) products are well accepted in human nutrition compared with other grains. In terms of nutrition, oat contains high concentration of protein with beneficial amino acid composition, advantageous profile of fatty acids, with high amount of PUFA, excellent source of different dietary fibre, starch, phenolic compound, minerals, vitamins, and antioxidants. Moreover, $\beta$ - glucans which also exhibit an antioxidant capacity, including the soluble dietary fibre fraction of oats that participate in glucoregulation and causes a decrease in serum cholesterol levels in humans (Butt et al., 2008) ${ }^{[5]}$. Chickpea (Cicer arietinum) is a major pulse crop in India and accounts for more than $66 \%$ of total word production. 
Chickpea is a good source of carbohydrate, mineral, protein and its protein quality is similar to or better than other legumes such as black gram and green gram. It is a cholesterol free pulse and is a good source of dietary fiber, vitamin and minerals (Jukanti et al., 2012) ${ }^{[9]}$. Tulsi (Ocimum sanctum L.) is highly complex, containing many nutrients and other biologically active compounds. It contains vitamin $\mathrm{C}$ and A, minerals like calcium, zinc and iron as well as chlorophyll and many other phytonutrients (Anbarasu and vijayyalakshmi, 2007) ${ }^{[3]}$. Tulsi enhances efficient digestion, absorption of nutrients from foods and it has been used from ancient times in Ayurveda due to its anti oxidant, anti inflammatory, anti bacterial and immune enhancing properties (Sah et al., 2018) ${ }^{[15]}$. Composite flour technology refers to the process of mixing various different coarse cereals with pulse flour and medicinal plant leaves to make economic use of local cultivated crops to produce quality food products. To improve the nutritive value and consumption of coarse cereals, supplementation with chickpea and Tulsi leaves is of paramount importance due to nutritional as well as health benefits. Therefore, the present study was done to assess the physico-chemical properties and nutritional composition of coarse grains, Tulsi and their composite flours.

\section{Material and Methods \\ Procurement of material}

Seeds of pearl millet (HHB-272) were procured from bajra section, sorghum (HJ-513) and oat (HJ-8) from forage section, chickpea (HC-5) from pulses section and Tulsi leaves at optimum maturity level were procured in a single lot from Medicinal, Aromatic and Underutilized Plant Section, Department of Genetics and Plant Breeding, College of Agriculture, CCSHAU. All the seeds were cleaned and made free of dust, dirt and foreign material prior to primary processing. Raw materials were stored in clean and hygienic condition for further use.

\section{Processing of grains}

Blanching of pearl millet was done by the process of Chavan and Kachare (1994) ${ }^{[6]}$. The grains were subjected to boiling water (1:5 ratio of seeds to boiling water) for 30 seconds and dried at $50^{\circ} \mathrm{C}$ for 60 minutes.

Grains of oats were dehusked. Chickpea grains were soaked in tap water for $12 \mathrm{~h}$ at $37{ }^{\circ} \mathrm{C}$. Seed to water ratio of 1:5 (W/V) was used. The unimbibed seeds were discarded. The soaked seeds were germinated in sterile petri dishes lined with wet filter paper for $48 \mathrm{~h}$ at $37^{\circ} \mathrm{C}$ with frequent watering. The sprouts were rinsed in distilled water and dried at $50-55^{\circ} \mathrm{C}$. The Tulsi leaves (Ocimum sanctum L.) were trimmed in order to remove any dead or spoiled part. Then washed and dried at $-50^{\circ} \mathrm{C}$ temperature using freeze dryer. The dried unprocessed samples of sorghum, dehusked oat, germinated chickpea and blanched pearl millet were ground to fine powder in an electric grinder and then stored in plastic containers at room temperature $\left(32^{\circ} \mathrm{C}\right)$.

\section{Preparation of composite flours}

Ground and blanched pearl millet, unprocessed sorghum, dehusked oat, germinated chickpea and dried Tulsi leaves were used to prepare composite flours. Six types of composite flours were prepared.

Three composite flours were prepared from blanched pearl millet: sorghum: dehusked oat: germinated chickpea in ratios of 80:5:5:10 (Type-I), 60:10:10:20 (Type-II) and 40:15:15:30 (Type-III) (W/W), Three composite flours consisted of blanched pearl millet: sorghum: dehusked oat: germinated chickpea: Tulsi leaves in ratios of 80:5:5:5:5 (Type-IV), 60:10:10:15:5 (Type-V) and 40:15:15:25:5 (Type-VI) (W/W). The resultant blends were passed through 60 mesh size sieve to obtain uniform mixing.

\section{Determination of physico chemical and proximate composition}

All the samples of unprocessed grains (pearl millet, sorghum, oat and chickpea) were assessed for physico-chemical properties i.e. seed weight, seed volume, seed density, sedimentation value and water absorption capacity. Seed weight was determined according to AACC (2000) [1] procedure. Seed volume was determined by using the water displacement method described by Phirke et al. (1982) ${ }^{[12]}$. Sedimentation value in was determined according to procedure given by Mishra et al. (1998) ${ }^{[10]}$. Water absorption capacity was determined by Sathe et al. (1981) ${ }^{[16]}$.

All the samples of above grains and composite flours were also analyzed for proximate composition by employing the standard methods of analysis (AOAC 2012) ${ }^{[2]}$. Crude protein was estimated using micro-kjeldhal method using KEL PLUS Automatic Nitrogen Estimation System and a conversion factor of 6.25 was used to convert nitrogen into protein. Crude fat was determined by the soxhlet extraction method using Automatic SOCS plus Solvent Extraction System. Crude fibre was estimated by acid and alkaline digestion method using Automatic Fibra plus system. Statistical analysis of the obtained data was carried out using completely randomized design according to the standard method (Panse and Sukhatme, 1961) ${ }^{[11]}$.

\section{Results and Discussion}

The data presented in table 1 indicated that chickpea grains had significantly $(P<0.05)$ higher seed weight $(16.17 \mathrm{~g} / 100$ seeds), seed volume $(12.67 \mathrm{ml} / 100$ seeds $)$ and seed density $(1.28 \mathrm{~g} / \mathrm{ml})$ as compared to other grains. The seed weight was $1.01,2.19$ and $3.59 \mathrm{~g} / 100$ seeds in pearl millet, sorghum and oat, respectively.

The results for 1000-grain weight in present study are consistent to those reported by Cheik et al. (2006) [7] and Jambamma et al. (2011) ${ }^{[8]}$. The seed volume of oat $(5.00$ $\mathrm{ml} / 100$ seeds) was significantly higher than that of sorghum (2.00 $\mathrm{ml} / 100$ seeds) and pearl millet $(1.00 \mathrm{ml} / 100$ seeds $)$. Seed density ranged from 0.72 to $1.09 \mathrm{~g} / \mathrm{ml}$ among oat, sorghum and pearl millet. Similar results were also reported by Sehgal and Kawatra (2002) ${ }^{[17]}$.

The data presented in table 2 revealed that sedimentation value of different flours ranged from 7.33 to $15.33 \mathrm{ml}$ and water absorption capacity ranged from 0.93 to $2.17 \mathrm{ml} / \mathrm{g}$. Sedimentation value and water absorption capacity were significantly higher in sorghum and lower in chickpea flour. The values obtained are comparable to the results obtained earlier by Sikandra and Boora (2007) ${ }^{[19]}$ and Sibian et al. $(2013)^{[18]}$

The data pertaining to proximate composition of different grains and Tulsi leaves has been presented in table 3 . The moisture content of Tulsi leaves was 86.35 per cent which was significantly higher than other grains. Sarfraj et al. (2011) ${ }^{[14]}$ and Tewari et al. (2012) ${ }^{[20]}$ also reported similar moisture content for Tulsi leaves. Sorghum grains (8.71\%) had significantly higher moisture content than other grains, whereas moisture content did not differ significantly among pearl millet, oat and chickpea. The protein content was significantly higher in chickpea $(20.27 \%)$ followed by oat 
$(12.40 \%)$, pearl millet $(11.67 \%)$ and sorghum $(10.21 \%)$. The protein content $(1.02 \%)$ of Tulsi leaves was significantly lower. Crude fat content of pearl millet (5.97\%) was significantly higher than other grains and Tulsi leaves $(1.27 \%)$ had significantly lowest amount. Crude fibre content was observed to be significantly higher in Tulsi leaves $(6.83 \%)$ followed by chickpea (4.23\%), oat $(3.53 \%)$, sorghum $(1.87 \%)$ and pearl millet (1.53\%).

The ash content was significantly higher in Tulsi leaves (9.65\%), whereas, it ranged from 1.73 to 3.49 per cent among other grains. The data regarding proximate composition of composite flours has been presented in table 4 . The moisture content of different combinations of composite flours ranged from 6.92 to 7.15 per cent, whereas, in Tulsi leaves powder supplemented composite flours it ranged from 7.82 to 8.10 per cent. The crude protein content of composite flours differs significantly and it increases as the level of chickpea flour increases. Maximum crude protein content was found in Type-III (14.15\%) followed by Type-II (13.27\%) and Type-I $(12.54 \%)$. The values for crude protein content of the composite flours supplemented with Tulsi leaves powder showed significant $(P<0.05)$ difference and it ranged from 11.43 to 13.13 per cent. A significant difference was observed in the fat content of different types of composite flours. The fat content of Type-I, Type-II and Type-III composite flour was $5.37,4.75$ and 4.10 per cent, respectively.

Fat content of Type-I composite flour was significantly $(P<0.05)$ higher as compared to Type-II and Type-III composite flour. Crude fat content of Tulsi leaves powder supplemented composite flours varied significantly $(P<0.05)$ from 4.00 per cent to 5.27 per cent. Highest amount of crude fat was found in Type IV composite flour and lowest in TypeVI composite flour. Different combinations of composite flours had significant $(P<0.05)$ difference in crude fibre content. As pearl millet replaced with sorghum, oat and chickpea crude fibre content increased significantly $(P<0.05)$ and being maximum $(2.73 \%)$ at Type-III composite flour followed by Type-II $(2.30 \%)$ and Type-I (1.93\%) composite flour. Similarly, the same trend was observed in composite flours enriched with Tulsi leaves powder. Composite flour with combination of Type-VI showed significantly $(P<0.05)$ higher crude fiber content. The crude fiber content of TypeIV, Type-V and Type-VI composite flours was 2.07 per cent,
2.47 per cent and 2.83 per cent, respectively. Ash content of Type-I, Type-II and Type-III, Type-IV, Type-V and Type-VI composite flours was observed as 2.07, 2.39, 2.46, 2.39, 2.68 and 2.87 per cent, respectively. Composite flours prepared from Type-III and Type-VI composition had significantly $(P<0.05)$ higher amount of ash in their respective group. The ash content was found to be significantly $(P<0.05)$ higher in Tulsi leaves powder based composite flours than unsupplemented composite flours.

Table 1: Physicochemical properties of grains

\begin{tabular}{|c|c|c|c|}
\hline Grains & $\begin{array}{c}\text { Seed weight } \\
\text { (g/100 seeds) }\end{array}$ & $\begin{array}{c}\text { Seed Volume } \\
(\mathbf{m l} / \mathbf{1 0 0 s e e d s})\end{array}$ & $\begin{array}{c}\text { Seed Density } \\
(\mathbf{g} / \mathbf{m l})\end{array}$ \\
\hline Pearl Millet & $1.01 \pm 0.05$ & $1.00 \pm 0.00$ & $1.01 \pm 0.05$ \\
\hline Sorghum & $2.19 \pm 0.02$ & $2.00 \pm 0.00$ & $1.09 \pm 0.01$ \\
\hline Oat & $3.59 \pm 0.10$ & $5.00 \pm 0.00$ & $0.72 \pm 0.02$ \\
\hline Chickpea & $16.17 \pm 0.06$ & $12.67 \pm 0.17$ & $1.28 \pm 0.02$ \\
\hline CD $(P \leq 0.05)$ & 0.21 & 0.28 & 0.09 \\
\hline
\end{tabular}

Values are mean \pm SE of three independent determinations

Table 2: Physicochemical properties of flours

\begin{tabular}{|c|c|c|}
\hline Flours & $\begin{array}{c}\text { Sedimentation Value } \\
(\mathbf{m l})\end{array}$ & $\begin{array}{c}\text { Water absorption } \\
\text { capacity }(\mathbf{m l} / \mathbf{g})\end{array}$ \\
\hline Pearl Millet & $14.67 \pm 0.33$ & $1.22 \pm 0.02$ \\
\hline Sorghum & $15.33 \pm 0.33$ & $2.17 \pm 0.17$ \\
\hline Oat & $12.33 \pm 0.33$ & $1.70 \pm 0.03$ \\
\hline Chickpea & $7.33 \pm 0.33$ & $0.93 \pm 0.03$ \\
\hline CD $(P \leq 0.05)$ & 1.10 & 0.29 \\
\hline
\end{tabular}

Values are mean \pm SE of three independent determinations

Table 3: Proximate composition of grains and Tulsi leaves (\%, dry weight basis)

\begin{tabular}{|c|c|c|c|c|c|}
\hline Grains & Moisture & $\begin{array}{c}\text { Crude } \\
\text { Protein }\end{array}$ & $\begin{array}{c}\text { Crude } \\
\text { Fat }\end{array}$ & $\begin{array}{c}\text { Crude } \\
\text { Fibre }\end{array}$ & Ash \\
\hline $\begin{array}{c}\text { Pearl } \\
\text { Millet }\end{array}$ & $6.83 \pm 0.26$ & $11.67 \pm 0.15$ & $5.97 \pm 0.07$ & $1.53 \pm 0.03$ & $1.95 \pm 0.02$ \\
\hline Sorghum & $8.71 \pm 0.11$ & $10.21 \pm 0.15$ & $1.70 \pm 0.03$ & $1.87 \pm 0.03$ & $1.73 \pm 0.06$ \\
\hline Oat & $6.73 \pm 0.05$ & $12.40 \pm 0.15$ & $3.92 \pm 0.02$ & $3.53 \pm 0.07$ & $3.15 \pm 0.01$ \\
\hline Chickpea & $6.85 \pm 0.08$ & $20.27 \pm 0.14$ & $2.77 \pm 0.04$ & $4.23 \pm 0.03$ & $3.49 \pm 0.06$ \\
\hline $\begin{array}{c}\text { Tulsi } \\
\text { leaves }\end{array}$ & $86.35 \pm 0.32$ & $1.02 \pm 0.14$ & $1.27 \pm 0.02$ & $6.83 \pm 0.03$ & $9.65 \pm 0.04$ \\
\hline $\begin{array}{c}\text { CD } \\
(P \leq 0.05)\end{array}$ & 0.62 & 0.46 & 0.13 & 0.14 & 0.14 \\
\hline
\end{tabular}

Values are mean \pm SE of three independent determinations

Table 4: Proximate composition of composite flours with and without Tulsi (\%, dry weight basis)

\begin{tabular}{|c|c|c|c|c|c|}
\hline Composite Flours & Moisture & Crude Protein & Crude Fat & Crude Fibre & Ash \\
\hline \multicolumn{7}{|c|}{ Blanched Pearl Millet: Sorghum: Oat: Germinated Chickpea } \\
\hline Type-I 80:5:5:10 & $6.93 \pm 0.13$ & $12.54 \pm 0.15$ & $5.37 \pm 0.04$ & $1.93 \pm 0.09$ & $2.07 \pm 0.06$ \\
\hline Type-II 60:10:10:20 & $7.02 \pm 0.12$ & $13.27 \pm 0.14$ & $4.75 \pm 0.06$ & $2.30 \pm 0.06$ & $2.39 \pm 0.04$ \\
\hline Type-III 40:15:15:30 & $7.15 \pm 0.11$ & $14.15 \pm 0.15$ & $4.10 \pm 0.09$ & $2.73 \pm 0.08$ & $2.46 \pm 0.04$ \\
\hline \multicolumn{2}{|c|}{ Blanched Pearl Millet: Sorghum: Oat: Germinated Chickpea: Tulsi leaves Powder } \\
\hline Type-IV 80:5:5:5:5 & $7.82 \pm 0.12$ & $11.43 \pm 0.05$ & $5.27 \pm 0.04$ & $2.07 \pm 0.07$ & $2.39 \pm 0.02$ \\
\hline Type-V 60:10:10:15:5 & $8.00 \pm 0.06$ & $12.40 \pm 0.15$ & $4.68 \pm 0.16$ & $2.47 \pm 0.06$ & $2.68 \pm 0.04$ \\
\hline Type-VI 40:15:15:25:5 & $8.10 \pm 0.04$ & $13.13 \pm 0.00$ & $4.00 \pm 0.03$ & $2.83 \pm 0.03$ & $2.87 \pm 0.04$ \\
\hline CD $(P \leq 0.05)$ & 0.32 & 0.38 & 0.26 & 0.22 & 0.13 \\
\hline
\end{tabular}

Values are mean \pm SE of three independent determinations

\section{Conclusion}

It may be concluded from the present study that the physicochemical properties are important from commercial point of view because they help to know the nature of developed product and development of composite flour from coarse cereals is nutritionally superior and addition of Tulsi leaves powder increased the ash and fibre contents of composite flours. Thus, consumption of Tulsi leaves in our daily diet helps in prevention of many diseases.

\section{Acknowledgements}

We would like to acknowledge the funds provided by Indian Council of Research, New Delhi, India under the Emeritus Scientist Scheme. 


\section{References}

1. AACC. Approved Methods of Analysis, The American Association of Cereal Chemists, St. Paul, MN 2000.

2. AOAC. Official Methods of Analysis, $1^{\text {th }}$ edition. Association of the Official Analytical Chemists 2012. Washington D.C, USA.

3. Anbarasu K, Vijayyalakshmi G. Improved shelf life of protein-rich tofu using Ocimum sanctum (Tulsi) extracts to benefit Indian rural population. Journal of Food Science 2007;72(8):M-300-305.

4. Bouis HE. Enrichment of food staples through plant breeding: a new strategy for fighting micronutrient malnutrition. Nutrition 2000;16:701-704.

5. Butt SM, Tahir-Nadeem M, Khan MKI, Shabi R, Butt MS. Oat: unique among the cereals. European Journal of Nutrition 2008;47:68-79.

6. Chavan JK, Kachare DP. Effect of seed treatment on lipolytic deterioration of pearl millet flour during storage. Journal of Food Science and Technology 1994;31(1):8081.

7. Cheik QAT, Aly S, Yaya B, Alfred ST. A comparative study on nutritional and technological quality of fourteen (14) cultivars of pearl millet (Pennisetum glaucum (L.) in Burkina Faso. Pakistan Journal of Nutrition 2006;5:512521.

8. Jambamma Kumari AI, Kailappan R. Study of physicochemical properties of food grain sorghum and product ready-to-cook mix food from sorghum. International Journal of Recent Scientific Research 2011;1(3):96-99.

9. Jukanti AK, Gaur PM, Gowda CL, Chibbar RN. Nutritional quality and health benefits of chickpea (Cicer arietinum L.): A Review. The British Journal of Nutrition 2012;108Suppl 1(S1):S11-26.

10. Mishra BK, Gupta RK, Ram S. Protocol for evaluation of wheat quality. Directorate of Wheat Research, Karnal 1998, 1-60.

11. Panse YG, Sukhatme PU. Statistical methods of agricultural workers. 2nd Edn. Indian Council of Agricultural Research, New Delhi 1961, 12-87.

12. Phirke AV, Chavan JK, Jadhav SJ, Salunkhe DK. Physical properties, chemical composition, cookabil1961ity and solubilization of proteins of dry beans (Phaseolus vulgaris L.). Legume Research 1982;5:91-96.

13. Rai KN, Gowda CLL, Reddy BVS, Sehgal S. Adaptation and potential uses of sorghum and pearl millet in alternative and health foods. Comprehensive Reviews in Food Science and Food Safety 2008, 340-352.

14. Sarfraj Z, Anjum FM, Khan MI, Arshad MS, Muhammad N. Characterization of basil (Ocimum basilicum L.) parts for antioxidant potential. African Journal of Food Science and Technology 2011;2(9):204-213.

15. Sah AK, Vijaysimha M, Mahamood Md. The Tulsi, queen of green medicines: biochemistry and pathophysiology - a review. International Journal of Pharmaceutical Sciences Review and Research 2018;50(2):106-114.

16. Sathe SK, Ponte IG, Rangnekar PD, Salunkhe DK. Effects of addition of great northern bean flour and protein concentrates on the rheological properties of dough and baking quality of bread. Cereal Chemistry 1981;58:97-100.

17. Sehgal S, Kawatra A. Processing of millets for value addition and development of health foods (NATP-RNPSI) 2002 .
18. Sibian MS, Saxena DC, Riar CS. Study of absorption behaviour, functional and pasting properties of pearl millet soaking under different chemical stresses. International Journal of Agriculture and Food Science Technology 2013;4(4):347-352.

19. Sikandra, Boora P. Physico-chemical parameters, proximate composition and anti-nutrients in sorghum, wheat and chickpea varieties. Forage Research 2007;33(1):56-60.

20. Tewari D, Pandy HK, Meena HS, Manchanda A, Patni P. Pharmacognostical, biochemical and elemental investigation of Ocimum basilicum plants available in western Himalayas. International Journal of Research in Pharmaceutical and Biomedical Sciences 2012;3(2):2229-3701. 